\title{
The Effect of Capital Aset and Liability Ratio on Non-Performing Loan
}

\author{
Herman Ruslim and Christopher Hartawan Bengawan \\ Magister Akuntansi Fakultas Ekonomi dan Bisnis Universitas Tarumanagara, Jakarta \\ Email: herman.ruslim@gmail.com
}

\begin{abstract}
The purpose of this study is to analyze the effect of capital adequacy ratio (CAR), loan to deposit ratio (LDR) and inefficiency on non-performing loans at commercial banks in Indonesia. The population used as the object of research amounted to 45 banks, while only 41 banks that fit the research criteria and serve as a research sample. The research period is 2016-2018, so the amount of data observed is 123 data. This study uses panel data with secondary data types. This research was processed by multiple linear analysis of panel data with the help of software e-views version 9.00. The result showed that CAR, LDR, and inefficiency simultaneously affected NPL. Partially, CAR showed a negative result but does not significantly influence NPL. While LDR and inefficiency proved to be a positive and significant effect on NPL.
\end{abstract}

Keywords: NPL, CAR, LDR, inefficiency.

\section{INTRODUCTION}

Banking has long been a financial institution that has played an important role in economic activity. The big role of banking does not only affect the macroeconomy, but it also influences microeconomic activities. According to the Law on Banking: "Banks are business entities that collect funds from the public in the form of deposits and distribute them to the public in the form of credit and or other forms to improve the lives of many people."

There are two types of banks, namely: Commercial Banks and Rural Credit Banks. Then the commercial banks are divided into 2 types, namely conventional banks and Islamic banks. Activities undertaken by commercial banks include raising funds and channeling them to the public who need funds, whether in the form of credit or financing. One of the biggest banking income is derived from lending.

(Setiyaningsih et al., 2015) mentioned that the income earned by conventional commercial banks is inseparable from credit risk. Credit risk (Non-Performing Loan) is the risk arising from unpaid by the customer and exceeds the specified time. (Dwihandayani, 2017) stated that "NPL is one of the key indicators to assess the performance of bank functions. That is because a high NPL is an indicator of banks failing in managing a business, causing liquidity, solvency, and vulnerability problems.

Based on Bank Indonesia Circular Number 3/30 / DPNP, bank credit risk is measured using a Non-Performing Loan (NPL) ratio. According to Bank Indonesia Regulation No. 15/2/PBI/2013 concerning Determination of the Status and Follow-Up to Conventional Commercial Bank Supervision Article 4 paragraph 2 letter (d) revealed that a bank is stated 
to have the potential to endanger difficulties if the Non-Performing Loan is net more than $5 \%$ of the total credit. If the Non-Performing Loan level exceeds 5\% then the health of the bank is disturbed. This also indicates that the bank is not managing its lending properly. High non-performing loans will cause banks to strengthen their capital structure. Strengthening the capital structure directly will also reduce the ability of banks to expand credit in the real sector.

The following is a statistically high graph of NPLs for conventional commercial bank categories in Indonesia from 2015-2018. The values shown on the graph are gross NPL and net NPL values in the fourth quarter of each year.

Figure 1. Conventional Commercial Bank NPL statistics as per quarter IV from 2015- 2018

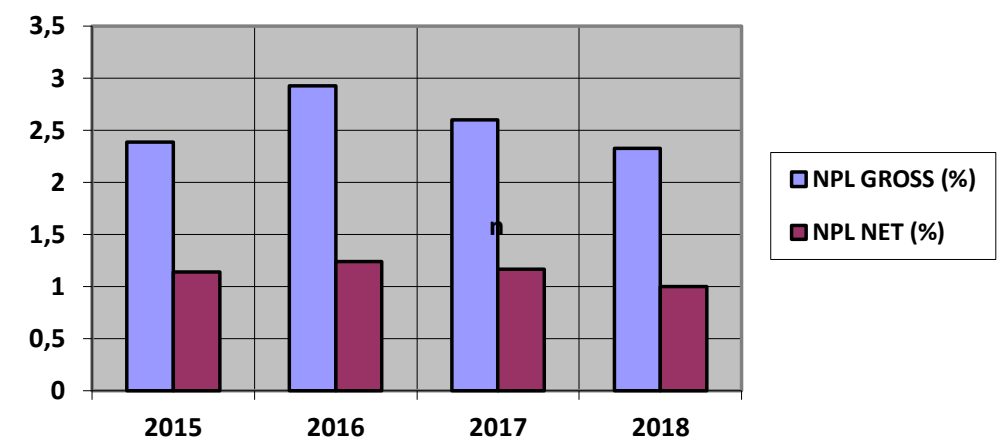

Source: Self-professed from SIP OJK

Based on these data, the NPL level from 2015 to 2018 has not exceeded the safe limit of $5 \%$. The net NPL level is quite stable at between 1-1.5\%. However, what needs to be watched out for is phenomena where there is news that several large companies have bad credit to several banks in Indonesia. Unmitigated credit granted to the company is worth millions of dollars.

Quoted from tirto.id on July 24, 2019, it was reported that one of the subsidiaries of the largest Duniatex group, PT Duta Merlin Dunia Textile (DMDT) was downgraded by the S\&P Global Rating. The story began with DMDT which issued bonds worth 300 million US dollars in March 2019. The bonds were welcomed positively by investors and even the interest was up to three times the value of the bonds. Then at the end of June 2019 the DMDT bond rating from the previous BB- was reduced by 6 levels to CCC-.

Quoted from Bisnis.com on July 23, 2019, a subsidiary of DMDT reportedly failed to pay interest and principal bonds worth the US \$ 11 million. Some government and private banks also have credit in the company. According to JP Morgan records the banks are Mandiri Bank, Indonesia Exim, BRI Syariah, Panin Syariah, Bank Muamalat, BPD Central Java, Rabobank, BPD Banten, BNI Syariah, and Nobu Bank.

The default was a strong indication of the potential for non-performing loans to banks in Indonesia. For this reason, the banking and related financial services authorities must try to suppress the NPL to maintain the health of the bank's condition. If the NPL is at a high level it will certainly have a broad impact on the economy and the sustainability of banks in 
Indonesia. Therefore it is necessary to further examine what are the factors that influence Non-Performing Loans at commercial banks.

As we know together Article 2 of the Banking Law stated that "Indonesian banks in conducting their business are based on economic democracy by using the precautionary principle." The precautionary principle in a bank also applies in the provision of credit loans to customers. Before giving credit to bank customers usually expect the principle of "5C" in granting credit loans. The 5Cs referred to are character (customer background), capacity (the ability of customers to pay credit), capital (capital), collateral (collateral) and condition (economic conditions).

With some news about customers who have failed to make credit payments (NonPerforming Loans). As we know, banks have carried out very strict procedures and adhere to the principle of prudence. For this reason, researchers are interested in examining what other factors influence to reduce the number of bad loans in the banking world, especially in bank performance.

With the adoption of Statement of Financial Accounting Standards (SFAS) 71 starting in 2020 as a substitute for Statement of Financial Accounting Standards (SFAS) 55 that will be revoked, it will potentially erode profits in the banking industry. This is due to the necessity of banks to prepare the effect of background loss or commonly abbreviated as (EBS). If in Statement of Financial Accounting Standards (SFAS) 55 a new effect of background loss will be formed at the time of late payment, Statement of Financial Accounting Standards 71 will be calculated from the beginning of the loan using the expected loss method. The obligation to follow this new Statement of Financial Accounting Standards could result in a decrease in the capital adequacy ratio (CAR) and also bank profits. The projection of the additional effect of background loss will later be charged to retained earnings following the provisions.

\section{THEORETICAL REVIEW}

Information Asymmetry Theory. (Kingu et al., 2016) mentioned that information asymmetry theory occurs when one party in a transactional relationship has more information about a transaction than another party. In financial decisions, the asymmetric information literature looks at the impact of decisions based on differences in the information available to both parties. (Sartono, 2015) stated that the potential impact that might occur in this information asymmetry is the emergence of market failures. This asymmetry of information causes market failure because lenders (creditors) cannot distinguish which borrowers are eligible funds, and which borrowers are not feasible funds. All borrowers are subject to the normal interest rate.

(Kingu et al., 2017) in line with these adverse conditions, banks may lack the ability to manage credit risk and be less able to manage operational costs. According to (Berger and De Young, 1997), bank managers tend to inject more resources into managing and monitoring bad loans. This, in the long run, will increase by operating costs over interest income.

Agency Theory. Based on agency theory in (Sartono, 2015) managers of a company are appointed by the shareholders (principal) with the task of maximizing the prosperity of the shareholders. But in practice, there is often a conflict between the principal and the manager. 
On the one hand, shareholders want to maximize their prosperity by drinking unnecessary expenses, but on the other hand managers desire to enlarge the company's scale by expanding. The motives of the manager are to increase the manager's power, status, and salary.

Other potential conflicts can occur between stockholders and debt holders. Creditors provide loans to companies with interest rates based on asset risk, future risk and the company's capital structure in the future. If the stockholders through their managers decide to expand the business, it will result in increased risk. The increase in risk will also increase the level of profit implied by debt. If the investment is successful then the profit will be the right of the shareholders, but if the expansion fails then the creditor must bear the loss. So according to agency theory in (Sartono, 2015), this investment is only good for shareholders, but not good for creditors.

The first independent variable (X1) in this study is the capital adequacy ratio (CAR). CAR is a ratio to measure the bank's capital adequacy to total risk-weighted assets (RWA). The provision of own capital is to cover the risks that might occur in resulting from the financing of productive assets that contain risks. The higher the bank's capital, the bank is predicted to have better recovery ability if it experiences bad credit. According to (Susanto and Kholis, 2016), Capital Adequacy Ratio is a ratio that showed the extent to which a bank's capital capacity can absorb the risk of possible credit defaults.

Based on the research of (Kingu et al., 2017), (Harutiyansari, 2018) and (Astrini et al., 2018), capital adequacy has a significant and negative effect on none-performing loans. The result is shown that the higher the capital ratio, the lower the NPL and vice versa. This result supports the moral hazard theory, which argues that banks with large capital tend to have lower NPLs, while banks with small capital tend to have higher NPLs. The same result was also mentioned in (Riyadi et al., 2014), (Abid et al., 2014), (Makri et al., 2014), (Anwar and Suneanah, 2016) and (Mentari, 2017) where the capital adequacy ratio variable influences non-performing loans but has a positive direction. Different research results are found in (Barus and Erick, 2016). The research revealed that the capital adequacy ratio did not affect non-performing loans.

The second independent variable (X2) in this study is the Loan to Deposit Ratio (LDR). LDR is a ratio that compares total loans provided by banks compared to total third party funds. This ratio aims to determine the level of ability of banks in channeling credit obtained from third-party funds. The more credit that is channeled by banks to the public, it will automatically increase the benefits of banks. Increasing bank profits from providing credit to the public will increase the credit risk of lending. And vice versa, if the credit extended by banks is small, the risk of bad loans owned by banks is also low.

In the research results (Riyadi et al., 2014) stated that loan to deposit significantly influences non-performing loans. In his research it is concluded that the higher the amount of credit extended, the less non-performing loans at commercial banks would be reduced. Research conducted by (Mentari, 2017), (Harutiyansari, 2018) found that loan to deposit has a positive effect on non-performing loans in conventional commercial banks in Indonesia. The results of (Barus and Erick's, 2016) study stated that the loan to deposit ratio has a significant effect on non-performing loans. In this study LDR has a significantly positive effect, this is because the amount of third party funds raised by banks is increasing. 
This makes banks will also increase lending by banks. With more loans being given then the possibility of bad loans will also increase.

The third independent variable (X3) in this study is the Operational Expense to Operating Income (BOPO). BOPO is a ratio that shows the level of efficiency of bank management in carrying out its operational activities. A bank is revealed to be efficient if its BOPO value is low, conversely, a high BOPO value indicates that the bank is wasteful. If a bank has a good level of efficiency, the non-performing loan will be small, this is because there are remaining operational benefits that can be used as a reserve to replace credit risk. In other words, a low BOPO will reduce the NPL level of commercial banks, and vice versa. The framework of thought in this study is illustrated below:

Figure 3. Research Model

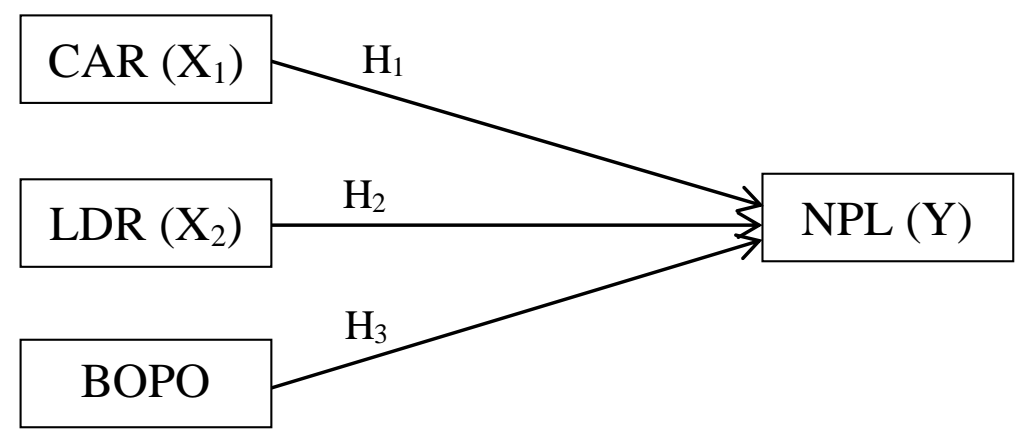

Explanation

NPL $=$ Non-Performing Loan

CAR $=$ Capital Adequacy Ratio

LDR $=$ Loan to Deposit Ratio

$\mathrm{BOPO}=$ Operational Costs Operating Income

Based on the research literature that has been presented previously, the hypothesis of this study are as follows:

Ha1: Capital Adequacy Ratio (CAR) is a negative predictor of Non-Performing Loans.

Ha2: Loan to Deposit Ratio (LDR) is a positive predictor of Non-Performing Loans.

Ha3: Operating Expenses on Operating Income (BOPO) is a positive predictor of NonPerforming.

\section{METHODOLOGY}

This research belongs to the type of causal study research design. The data used in this study is a panel data type. The purpose of this study is to obtain empirical evidence regarding the effect of capital adequacy ratio, loan to deposit ratio and BOPO on nonperforming loans at commercial banks in Indonesia. This research is descriptive. The population used in this study is all Banks listed on the Indonesia Stock Exchange, namely 45 banks. Four banks do not fit the criteria so that the sample used in this study amounted 
to 41 banks. This study uses panel data from 41 Bank's annual reports and financial statements in Indonesia in the 2016-2018 period, so there are 123 data samples.

Table 1. Sample Selection Criteria

\begin{tabular}{lc}
\hline \multicolumn{1}{c}{ Criteria } & Total \\
\hline Banking companies listed on the IDX of the year 2016-2018 & 45 \\
Banking that is not a conventional commercial bank & $(3)$ \\
Banking companies that were delisted between years 2016-2018 & $(1)$ \\
Number of company samples used & 41 \\
\hline Number of sample company data used (times three years) & $\mathbf{1 2 3}$ \\
\hline
\end{tabular}

Table 2. Proxy Variables in Research

\begin{tabular}{cc}
\hline \multicolumn{1}{c}{ Variables } & Ratio \\
\hline Non-Performing Loan & NPL $=\frac{\text { Non }- \text { performing loans }}{\text { Total Credit }}$ \\
\hline Capital Adequacy Ratio & CAR $=\frac{\text { Capital }}{\text { Risk Weighted assets }}$ \\
\hline Loan to Deposit & LDR $=\frac{\text { Credit }}{\text { Third }- \text { party funds }}$ \\
\hline $\begin{array}{l}\text { Operating Expenses on } \\
\text { Operating Income }\end{array}$ & BOPO $=\frac{\text { Total operational expenses }}{\text { total Operating income }}$ \\
\hline
\end{tabular}

Source: (Operationalization of variables)

* Credit is credit given to third parties (not including credit to other banks)

** Third-party funds include current accounts, savings accounts, deposits (excluding demand deposits and interbank deposits).

In this research, data is proceeded and tested, which used multiple linear regression models. Multiple regression analysis aims to predict two or more effects of predictor variables on one dependent variable. Processing and testing of this research are planned to use e-views software version 9.

The equation of the multiple regression model used in this study is:

$$
\mathrm{NPL}_{\mathrm{it}}=\mathrm{a}-\beta_{1} \mathrm{CAR}_{\mathrm{it}}+\beta_{2} \mathrm{LDR}_{\mathrm{it}}+\beta_{3} \mathrm{BOPO}_{\mathrm{it}}+\mathrm{e}_{\mathrm{it}}
$$

Explanation

NPL: Non-Performing Loan

a : constant

$\beta_{(1,2,3)}:$ regression coefficient

CAR : Capital Adequacy Ratio

LDR : Loan to Deposit Ratio

BOPO : Operating Expenses on Operating Income

e : error (explained by other variables) 


\section{RESULT AND DISCUSSION}

Descriptive statistics. Descriptive statistics are used to describe the characteristics of the variables used in the study. General description of variable characteristics can be described using minimum, maximum, mean (average value), and standard deviation values.

Table 3. Statistical Result of Research Objects

\begin{tabular}{lcccc}
\hline \hline & $\mathbf{Y}$ & $\mathbf{X 1}$ & $\mathbf{X 2}$ & $\mathbf{X 3}$ \\
\hline \hline Mean & 0.033085 & 0.218079 & 0.843398 & 0.926344 \\
Median & 0.028300 & 0.203000 & 0.861800 & 0.872000 \\
Maximum & 0.157500 & 0.664300 & 1.452600 & 2.352000 \\
Minimum & 0.000000 & 0.100400 & 0.419900 & 0.582000 \\
Std. Dev. & 0.021064 & 0.075086 & 0.147711 & 0.256626 \\
Observations & 123 & 123 & 123 & 123 \\
\hline
\end{tabular}

Explanation:

Source: (Output E-views Version 9, 2018)

Y: Non-Performing Loan (NPL)

X1: Capital Adequacy Ratio (CAR)

X2: Loan to Deposit Ratio (LDR)

$\mathrm{X} 3$ : Operating Expenses on Operating Income (BOPO)

Based on observations from 123 data, Non-Performing Loans have a minimum value of 0.000000 that value is represented from the financial statements of PT Bank National Nobu Tbk in 2016. The maximum NPL value showed a figure of 0.157500 , the value is represented in the financial statements of PT Bank Yudha Bhakti Tbk in 2018 The average value for NPL between 2016 and 2018 is 0.033085 with a standard deviation of 0.021064 . Standard deviations are used to determine how the data is distributed in samples, and how close the individual data points are to the mean sample values.

Capital Adequacy Ratio (CAR) has a minimum value of 0.100400 , the figure is represented in the financial statements of PT Bank Pembangunan Daerah Banten Tbk in 2018. The maximum CAR value is 0.664300 , this figure is represented by Bank Ina Perdana Tbk in the 2017 financial statements. CAR has a value of an average of 0.218079 with a standard deviation of 0.075086 .

Loan to Deposit (LDR) as a result of observation of 123 financial statement data recorded has a minimum value of 0.419900 , this figure is contained in the financial statements of PT Bank Mitraniaga Tbk in 2018. The maximum value of the LDR in 20162018 is 1.452600 , it can be shown from PT Bank's financial statements. Woori Saudara Indonesia 1906 Tbk in 2018. The mean value of the LDR is 0.843398 with a standard deviation of 0.147711 .

Operating Expenses against Operating Income (BOPO) of 41 companies in the 20162018 period were recorded to have a minimum value of 0.582000 , which is reflected in the annual financial statements of PT Bank Central Asia Tbk in 2018. The largest BOPO value in 2016-2018 was reported by PT Bank of India Indonesia Tbk in 2016 with a value of 
2.352000. The average value of BOPO in this study is 0.926344 with a standard deviation of 0.256626 .

\section{Test result}

Table 4. Test Result for the Determination and Adjusted R-Squared Coefficient Analysis Tests

\begin{tabular}{|c|c|c|c|}
\hline \multicolumn{4}{|c|}{$\begin{array}{l}\text { Dependent Variable: Y } \\
\text { Method: Panel EGLS (Cross-section random effects) } \\
\text { Weighted Statistics }\end{array}$} \\
\hline R-squared & 0.256522 & $\begin{array}{l}\text { Mean dependent } \\
\text { var. }\end{array}$ & 0.019017 \\
\hline $\begin{array}{l}\text { Adjusted R- } \\
\text { squared }\end{array}$ & 0.237779 & $\begin{array}{l}\text { S.D. dependent } \\
\text { var. }\end{array}$ & 0.015840 \\
\hline
\end{tabular}

Source: (Results of outputs e-views version 9, 2018)

From the result of the output e-views above, it can be shown that this study has an Adjusted R-Square value of 0.237779 . That is, $23.78 \%$ of the Non-performing Loan variable can be explained by the capital adequacy ratio, loan to deposit ratio and BOPO, while the remaining $76.22 \%$ is explained by other factors beyond this research.

Table 5. Result of F-Test

Dependent Variable: Y

Method: Panel EGLS (Cross-section random effects)

Total panel (balanced) observations: 123

Swamy and Arora estimator of component variances

\section{Weighted Statistics}

\begin{tabular}{llll}
\hline \hline F-statistic & 13.68616 & Durbin-Watson stat & 1.602340 \\
Prob. (F-statistic) & 0.000000 & & \\
\hline \hline
\end{tabular}

Source: (Result of outputs e-views version 9, 2018)

The P-value or Prob. (F-statistic) is 0.000000 and $<0.05$. This means that Ho is rejected and $\mathrm{Ha}$ is not rejected. So from this F-test, it can be stated that CAR, LDR, and BOPO jointly influence the Non-Performing Loans at conventional commercial banks in Indonesia. It also means that CAR, LDR, and BOPO simultaneously influence NPL. 
Table 5. Result of Regression Coefficient Variables in the Random Effect Model

Dependent Variable: Y

Method: Panel EGLS (Cross-section random effects)

Sample: 20162018

Periods included: 3

Cross-sections included: 41

Total panel (balanced) observations: 123

Swamy and Arora estimator of component variances

\begin{tabular}{crrrr}
\hline \hline Variable & Coefficient & Std. Error & t-Statistic & Prob. \\
\hline \hline C & -0.022661 & 0.015516 & -1.460491 & 0.1468 \\
X1 & -0.028505 & 0.025706 & -1.108912 & 0.2697 \\
X2 & 0.030487 & 0.013159 & 2.316742 & 0.0222 \\
X3 & 0.039133 & 0.006656 & 5.879261 & 0.0000 \\
\hline \hline
\end{tabular}

Source: (Result of outputs e-views version 9.0, 2018)

The linear equation of panel data in this study is as follows:

$$
\mathrm{Y}=-0.022661-0.028505 \mathrm{X}_{1}+0.030487 \mathrm{X}_{2}+0.039133 \mathrm{X}_{3}+\varepsilon_{\mathrm{i}}+u_{i t} \ldots \ldots \ldots
$$

Explanation

Y: Non-Performing Loan (NPL)

$\mathrm{X}_{1}$ : Capital Adequacy Ratio (CAR)

$\mathrm{X}_{2}$ : Loan to Deposit Ratio (LDR)

$\mathrm{X}_{3}$ : Operating Expenses on Operating Income (BOPO)

$\varepsilon_{i}$ : Random Error Term

$v_{i t}:$ Disturbance Term

Based on the coefficient test above, it can be shown that the constant value $(\beta 1)$ is 0.022661 . The value of the constant reflects the value of Non-Performing Loans of 0.022661 units if it ignores the entire influence of the independent variable.

The value of $\beta 2$ is equal to -0.028505 . This showed that every increase of one unit in the Capital Adequacy Ratio resulted in a reduction in the value of Non-Performing Loans of 0.028505 assuming that the other independent variables are fixed. This is shown the Capital Adequacy Ratio harms Non-Performing Loans. This situation showed that if the Capital Adequacy Ratio increases, it reduced the level of Non-Performing Loans of a bank. For this reason, banks that have their capital adequacy can reduce the risk of default / nonperforming loans.

The value of $\beta 3$ showed the number 0.030487 . This means that each increase in Loan to Deposit Ratio by one unit will result in an increase in the value of Non-Performing Loans of a bank by 0.030487 assuming that the other independent variables are fixed. This result concluded that the Loan to Deposit Ratio has a positive effect on Non-Performing Loans. 
In other words, the higher the ability of banks to extend credit from third party funds will increase the risk of bad credit.

The value of $\beta 4$ showed 0.039133 . This means that each increase in the ratio of operating expenses to operating income (BOPO) by one unit will increase the value of a bank's Non-Performing Loan by 0.039133 assuming that the other independent variables are fixed. This is shown that there is a positive correlation between BOPO and NPL. In other words, if a bank is inefficient in its operational activities, it will increase the risk of bad credit.

Table 6. Result of t-Test

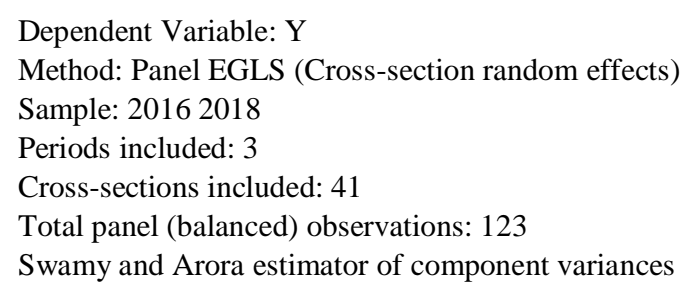

\begin{tabular}{ccc}
\hline \hline Variable & t-Statistic & Prob. \\
\hline \hline C & -1.460491 & 0.1468 \\
X1 & -1.108912 & 0.2697 \\
X2 & 2.316742 & 0.0222 \\
X3 & 5.879261 & 0.0000 \\
\hline \hline
\end{tabular}

Source: (Result of outputs e-views version 9, 2018)

Using $\alpha=0.05 / 2, \mathrm{df}(123)$; then the value of $\mathrm{t}$ table is $+/-1.9794$. Here are a few hypotheses to be tested:

\section{Hypothesis 1}

Ho1: Capital Adequacy Ratio has no negative effect on Non-Performing loans.

Ha1: Capital Adequacy Ratio has a negative influence on Non-Performing loans.

Based on the result of the t-test output above X1 has a t-statistic of -1.108912 with a prob. level of 0.2697. This means that the value of sig. is 0.2697> 0.05; then Ho1 is not rejected and Hal is rejected. The t-test result for this hypothesis 1 is that the Capital Adequacy Ratio has no negative effect on Non-Performing loans in conventional commercial banks in Indonesia.

\section{Hypothesis 2}

Ho2: Loan to Deposit does not have a positive effect on Non-Performing loans.

Ha2: Loan to Deposit has a positive influence on Non-Performing loans.

Based on the result of the t-test output above X2 has a t-statistic of 2.316742 and a prob. level of 0.0222 . This result showed that the value of sig $0.0222<0.05$; then the decision taken is rejected $\mathrm{H} 02$ and $\mathrm{Ha} 2$ not rejected. This means that Loan to Deposit has a positive influence on Non-Performing loans at conventional commercial banks in Indonesia. 


\section{Hypothesis 3}

Ho3: BOPO does not have a positive influence on Non-Performing loans.

Ha3: BOPO has a positive influence on Non-Performing loans.

Based on the result of the t-test output above X3 has a t-statistic of 5.879261 and the prob. value is 0.0000 . This means that the value of sig. $0.0000<0.05$, so that the decision on the third hypothesis is $\mathrm{Ho} 3$ is rejected and $\mathrm{Ha} 3$ is not rejected. Hence, it can be concluded that BOPO has a positive influence on Non-Performing loans at conventional commercial banks in Indonesia.

The t-test result for this hypothesis-1 is the Capital Adequacy Ratio does not harm Non-Performing loans in conventional commercial banks in Indonesia. T-test results for hypothesis-2 are Loan to Deposit has a positive influence on Non-Performing loans at conventional commercial banks in Indonesia. BOPO has a positive influence on NonPerforming loans in conventional commercial banks in Indonesia.

\section{DISCUSSION}

The Capital Adequacy Ratio (CAR) variable was found to have no effect on NonPerforming Loans at conventional commercial banks in Indonesia. This showed that the first alternative hypothesis was rejected and the first null hypothesis was not rejected. The result of this study is consistent with the research of (Barus and Erick, 2016) who also mentioned in their research that Capital Adequacy Ratio (CAR) does not influence the effect on NonPerforming Loans. But this is contrary to research from (Kingu et al., 2017), (Astrin et al., 2018), (Samsiah et al., 2019), (Riyadi et al., 2014), (Abid et al., 2014), (Makri et al., 2014), (Anwar and Suneanah, 2016) and (Mentari, 2017).

CAR is a ratio to measure the capital adequacy of a bank to the total risk-weighted assets (RWA). The provision of own capital is expected to be able to cover the risks that might occur. The risk in question could be the risk resulting from funding activities of productive assets that contain risks.

In this study, CAR was not proven to significantly influence Non-Performing Loans at conventional commercial banks in Indonesia. Although not significant, the direction is following the initial hypothesis. It is probably other factors such as the caution of bank management in managing lending that can keep the NPL ratio from being too high. Moreover, the CAR variable is not the main factor and has a significant influence on influencing the level of problem loans.

The Loan to Deposit (LDR) variable was found to have a positive and significant effect on Non-Performing Loans at conventional commercial banks in Indonesia. This result is indicated that the second alternative hypothesis is not rejected and reject the result of the second null hypothesis. The result of this study is consistent with research conducted by (Riyadi et al., 2014), (Pradana, 2018), (Mentari, 2017), (Barus and Erick, 2016) and (Astrini, et al., 2018). And contrary to the results of research by (Dewi and Ramantha, 2015), (Martina and Prastiwi, 2014), (Kingu et al., 2017) which revealed that LDR negatively affects NPL. (Kingu et al., 2017) stated that the possible explanation for this is because of the small banking market in which he researched, coupled with a very competitive landscape consisting of several borrowers, banks tend to provide large loans to several existing 
borrowers; corporate customers. They have a good track record, and hence reduce the possibility of an increase in the standard level. This study also contrasts with the results of (Wati et al., 2018) which mentioned that LDR does not affect NPL.

Loan to Deposit is a ratio that compares between total loans given by banks compared to total third party funds. LDR aims to determine the level of ability of banks in channeling credit obtained from third-party funds.

In this study, LDR has a positive and significant effect on Non-Performing Loans. Explanation of the result of this study is that if more credit is channeled by banks to the public, it will automatically increase the benefits of banks. The more the bank's profits from extending credit to the public, the greater the credit risk of lending. This can happen when viewed from a moral hazard theory which says, with bonuses and incentives targeted by bank managers, banks will deliberately reduce the safe level of credit applications from customers. This will certainly also increase the risk of non-performing loans.

The Variable Operational Expense on Operating Income (BOPO) is confirmed to have a positive and significant Non-Performing Loan effect on conventional commercial banks in Indonesia. This result indicated that the second alternative hypothesis is not rejected and reject the result of the second null hypothesis. The result of this study is consistent with research conducted by (Kingu et al., 2017), (Barus and Erick, 2016), (Mentari, 2017), (Harutiyansari, 2018) and (Riyadi et al., 2014). And the result of this study contradicted the research conducted by (Jusmansyah and Sriyanto, 2013) who stated that BOPO has no influence on NPLs in commercial banks.

(Raharjo et al., 2014) BOPO is a ratio that showed the level of efficiency of bank management in carrying out its operational activities. A bank is mentioned to be efficient if its BOPO value is low, conversely a high BOPO value indicated that the bank is wasteful. If a bank has a good level of efficiency, then the non-performing loan will be small, this is because there are remaining operational benefits that can be used as reserves to replace credit risk. In other words, low BOPO will reduce the NPL level of commercial banks. Vice versa, if the BOPO is high, the NPL level is also high.

BOPO has a positive and significant effect on Non-Performing Loans. BOPO is a ratio that showed the level of efficiency of bank management in carrying out operational activities. A bank is stated to be efficient if its BOPO value is low, conversely a high BOPO value indicated that the bank is wasteful. If a bank has a good level of efficiency, then the non-performing loan will be small, this is because there are remaining operational benefits that can be used as reserves to replace credit risk. In other words, low BOPO will reduce the NPL level of commercial banks. Vice versa, if the BOPO is high, the NPL level is also high.

The result of this study provided support for information asymmetry theory, bad selection theory, and bad management hypotheses. The poor management hypothesis states that low-cost efficiency is a signal that senior bank management is not sufficiently monitoring and controlling their expenses and they are inefficient or ineffective in guaranteeing, monitoring and controlling their loan portfolios. Also, these managers find it difficult to monitor and control borrowers after the issuance of the loan, which in the long run causes high amounts of bad loans in the future. This proved that the ability of bank management in controlling operational expenses to operating income will significantly reduce the occurrence of bad loans. 
Meeting the needs of the Bank's Minimum Capital Ratio or known CAR is determined by the BIS (Bank for International Settlement) of $8 \%$. The loan to deposit ratio set by Bank Indonesia is $78-92 \%$. When looking at the t-test result of each independent variable on the dependent variable, it can be shown that the BOPO has the most influence on nonperforming loans compared to other variables. But until now there has not been a safe limit for BOPO set by the OJK or Bank Indonesia in maintaining the NPL value. This can make input for the financial services authority (OJK) and also Bank Indonesia in providing rules regarding the safe limits of BOPO that must be owned by every bank in Indonesia.

\section{CONCLUSION}

This research was conducted to obtain empirical evidence about the effect of Capital Adequacy Ratio (CAR), Loan to Deposit Ratio (LDR), and operational expenses on Operating Income (BOPO) on Non-Performing Loans (NPLs) on conventional commercial banks in Indonesia. The study was conducted by taking secondary data from the company's 2016-2018 financial statements on the Indonesia Stock Exchange's website and the official banking website. Of the 45 banks listed on the IDX, only 41 companies fit the research criteria. The number of data samples in this study was 41 banks multiplied by three years, namely 123 samples. The data is processed using the help of e-views software version 9.0 using a random model of panel data regression effect.

The first variable Capital Adequacy Ratio (CAR) proved to not affect Non-Performing loans at conventional commercial banks in Indonesia. The result of this study is consistent with the research of (Barus and Erick, 2016) who also mentioned in their research that Capital Adequacy Ratio (CAR) does not influence the effect on Non-Performing Loans. But this is contrary to research from (Kingu et al., 2017), (Riyadi et al., 2014) and (Mentari, 2017), (Samsiah et al., 2019).

The second variable Loan to Deposit Ratio (LDR) is proven to have a significant and positive influence on Non-Performing loans in conventional commercial banks in Indonesia. The result of this study is consistent with research conducted by (Riyadi et al., 2014) and (Mentari, 2017), (Pradana, 2018), (Harutiyansari, 2018), (Barus and Erick, 2016). And contrary to the result of research (Martina and Prastiwi, 2014), (Kingu et al., 2017) stated that LDR negatively affects NPL.

The third variable in this determination is BOPO. BOPO is proven to have a positive influence on Non-Performing loans at conventional commercial banks in Indonesia. The result of this study is consistent with research conducted by (Kingu et al., 2017), (Barus and Erick, 2016), (Mentari, 2017), (Harutiyansari, 2018) and (Riyadi et al., 2014). And the result of this study contradicted the research conducted by (Jusmansyah and Sriyanto, 2013), (Wati et al., 2018) which mentioned that BOPO has no influence on NPLs at commercial banks.

The result of this study also indicated that the variable Capital Adequacy Ratio (CAR), Loan to Deposit Ratio (LDR), and operational expenses to Operating Income (BOPO) together (simultaneously) affect the Non-Performing Loans (NPLs) on commercial banks conventional in Indonesia.

This study is limited by only the test of three factors out of many factors that measure banking health. By looking at the results of the contribution of the variables used in this study amounted to only $23.78 \%$, researchers are further advised to look for and add other 
variables that are expected to increase the level of research contribution. Other variables that are recommended to be tested in future studies such as bank size, credit growth, and net interest margin. Also, for the $\mathrm{H} 1$ hypothesis rejected and in the direction of the study, the researcher suggests adding the number of years of research. With so expected, the CAR variable can give results with a higher level of significance.

When this research was completed, it was reported that several large companies had annexed small banks and the mergers of several banks both from domestic and foreign banks seemed to be a trend in the banking industry in Indonesia. In addition to the rampant mergers and acquisitions of banks, with the start of the adoption of Statement of Financial Accounting Standards 71 in Indonesia in early 2020 it will certainly affect the ratio of the soundness of the banking sector itself because banks are required to make an allowance for receivables when recognizing revenue as receivables. Researchers also suggest further research to include factors influencing the growth of fin-tech which is growing rapidly in Indonesia.

Suggestions from this research on bank management and OJK are to always increase the ratio of loan funds from third parties and make efficiency in running bank operations. This is intended to reduce the risk of bad credit in the banking world. Banks are also advised to tighten procedures for granting loans to prospective customers by prioritizing prudential principles and 5C. Researcher's suggestion for the financial services authority (OJK) and also Bank Indonesia in providing rules regarding the safe limits of BOPO that must be owned by every bank in Indonesia. Considering that of all the independent variables, only BOPO does not yet have a safe limit, and the BOPO variable is seen to provide the greatest significance value for NPL compared to other tested independent variables.

\section{REFERENCE}

Abid, L. Quertani, M.N., and Zouari-Ghorbel, S. (2014). Macroeconomic and BankSpecific Determinants of Household's Non-Performing Loans in Tunisia: A dynamic panel data. Procedia Economics and Finance, 13, 58-68.

Anwar,C. J., Suneanah. (2016). Pengaruh ROA dan CAR terhadap Kredit Macet (NPL) pada Bank Umum di Indonesia. Jurnal Unitra Ekonomi Qu. Vol 6, No.2 214-235.

Astrini, K.S., Suwendra, I. W., and Suwarna, I. K. (2018). Pengaruh CAR, LDR dan Bank Size terhadap NPL pada Lembaga Perbankan yang Terdaftar di Bursa Efek Indonesia. Bisma: Jurnal manajemen. Vol 4 no. 1, 34-41.

Barus, A.C., and Erick. (2016). Analisis Faktor yang Mempengaruhi Non Performing Loan pada Bank Umum di Indonesia. Jurnal Wira Ekonomi Mikrosil. Vol 6 No. 02, 113122.

Dewi, K. P., and Ramantha. (2015). Pengaruh Loan Deposit Rasio, Suku Bunga SBI, dan Bank Size Terhadap Nonperforming Loan. E-jurnal Akuntansi Universitas Udayana, 11.3: 909-920.

Dwihandayani, D. (2017). Analisis Kinerja Non Performing Loan (NPL) Perbankan di Indonesia dan Faktor-Faktor Yang Mempengaruhi NPL. Jurnal Ekonomi dan Bisnis. Vol 22 No. 3.265-274.

Ghozali, I. (2013). Aplikasi Analisis Multivariate dengan Program IBM SPSS21. Semarang: Badan Penerbit Universitas Diponegoro. 
Gujarati, D.N. (2004). Basic Econometrics, Fourth Edition. United States of America: The McGraw-Hill Companies.

Gumiwang, R. (2019, July 24). Mengenal Duniatex, Raksasa Tekstil yang Tengah Dirundung Krisis. Message posted to https://tirto.id/mengenal-duniatex-raksasatekstil-yang-tengah-dirundung-krisis-eeTQ. Diakses tanggal 14 September 2019.

Harutiyansari, D. (2018). Pengaruh Faktor Internal Bank Terhadap Non Performing Loan Dengan Metode Generalized Method Of Moment. Jurnal Manajemen Bisnis. Edisi 1, 27-36.

Jumansyah, M. and Sriyanto, A. (2013). Analisi Pengaruh CAR, BOPO dan ROA Terhadap Non Performance Loan. Jurnal Akuntansi dan Keuangan. Vol 2 No.1, 46-65.

Khadafi, M. (2019, July 23). Gagal Bayar Obligasi, Ini 10 ank Kreditur Anak Usaha Duniatex. Message posted to https://finansial.bisnis.com/read /20190723/90/1127653/gagal-bayar-obligasi-ini-10-bank-kreditur-anak-usahaduniatex. Diaksestanggal 14 September 2019.

Khumairoh, Kalbuana, N., dan Mulyati, H. (2016). Pengaruh Leverage, Profitabilitas, dan Ukuran Perusahaan Terhadap Nilai Perusahaan. Syariah Paper Accounting FEB UMS. halaman 71- 81.

Kingu, P.S, Macha, S., and Gwahula, R. (2017). Bank Specific Determinants of NonPerforming Loans: Empirical Evidence from Commercial Banks in Tanzania. The International Journal of Business \& Management. Vol 5 Issue 12, 18-28.

Makri, V., Tsagkanos, A., and Bellas, A. (2014). Determinants of Non-Performing Loans: The case of the Eurozone. Pandeconomicus, 61(2), 193.

Martina, E. and Prastiwi, D. (2014). Pengaruh Inflasi, Gross Domestic Product, Suku Bunga Kredit, Loan To Asset Ratio, Dan Kualitas Aktiva Produktif Terhadap Non Performing Loan. Junal Ilmu Manajemen. Vol. 2 No.2, 513-524.

Mentari, S.H. (2017). Pengaruh CAR, LDR dan BOPO terhadap Non Performing Loan Bank Umum di Indonesia. STIE Perbanas.

Peraturan Bank Indonesia Nomor 15/2/PBI/2013 Tentang Penetapan Status dan Tindak Lanjut Pengawasan Bank Umum Konvensional.

Peraturan Bank Indonesia No.17/11/PBI/2015 tentang Perubahan Atas Peraturan Bank Indonesia Nomor 15/15/PBI/2013 tentang Giro Wajib Minimum Bank Umum Dalam Rupiah Dan valuta Asing Bagi Bank Umum Konvensional.

Pradana, M. N. R. (2018). Pengaruh Likuiditas dan Variabel Eksternal Terhadap Non Performing Financing pada Bank Syariah. Ejournal STIE Wantara. Vol 13 No. 2, 131-144.

Raharjo, D. P. A., Setiaji, B. and Syamsudin. (2014). Pengaruh Rasio CAR, NPL, LDR, BOPO, dan Nim Terhadap Kinerja Bank Umum Di Indonesia. Jurnal Ekonomi Manajemen Sumber Daya. Vol 15, No.2, 7-12.

Riyadi, S., Iqbal, M., and Lauren, N. (2014). Strategi Pengelolaan Non Performing Loan Bank Umum yang Go Public. Jurnal Dinamika Manajemen. JDM Vol. 6 No.1, pp 8496.

Samsiah, S., Sari, D. P. and Sandri, S. H. (2019). Pengaruh Dana Pihak Ketiga, CAR, NPL terhadap Penyaluran Kredit Perusahaan Perbankan yang terdaftar pada BEI. Jurnal Akuntansi \& Ekonomika. Vol 9 No.2, 167-174.

Sartono, R.A. (2015). Manajemen Keuangan Teori dan Aplikasi Edisi 4. Yogyakarta: BPFE. Sekaran, U. and Bougie, R. (2013). Research Methods for Bussiness Sixth Edition. Willey. 
Setiyaningsih, Juanda, B. and Fariyanti, A. (2015). Faktor-Faktor yang Memperngaruhi Ratio Non Performing Loan (NPL). Jurnal Aplikasi Bisnis dan Manajemen (JABM). Vol. 1 No.1, 23-330.

Surat Edaran Bank Indonesia Nomor 3/30/DPNP Tanggal 14 Desember 2001. Tentang Pedoman Perhitungan Rasio Keuangan.

Surat Edaran Bank Indonesia Nomor 3/30/DPNP.

Susanto, H. and Kholis, N. (2016). Financial Ratio Analysis toward Profitability in Indonesian Banking. Jurnal EBBANK. Vol 7 No. 1, 11-22.

Wati, D., Susyanti, J. and Salim, A. (2018). Pengaruh Rasio Camels dan Bank Size terhadap Non Performing Loan. Jurnal Ilmiah Riset Manajemen. Vol 7 No.10, 36-57.

Widarjono, A. (2013). Ekonometrika : Pengantar dan Aplikasinya disertai Panduan Eviews. Yogyakarta: UPP STIM YKPN.

Winarno, W.W. (2015). Analisis Ekonometrika dan Statistika dengan EViews Edisi 4. Yogyakarta: UPP STIM YKPN. 